\title{
Movimentos indígenas latino-americanos da segunda metade do século XX: reflexões comparativas sobre processos decoloniais no Brasil e na Colômbia ${ }^{1}$
}

\author{
Latin american indigenous movements of the second \\ half of the twentieth century: comparative reflections on \\ decolonial processes in Brazil and Colombia
}

\author{
Fernando Roque Fernandes ${ }^{2}$ \\ Mauricio Alejandro Diaz Uribe ${ }^{3}$
}

DOI:http://dx.doi.org/10.20435/tellus.v19i39.539

\begin{abstract}
Resumo: No contexto de crise política e econômica que se materializou em vários países da América Latina na segunda metade do século XX, os povos indígenas articularam estratégias particulares na luta por direitos sociais frente aos Estados Nacionalistas, a partir de um processo histórico de mobilizações e demandas étnicas de âmbito nacional e internacional. Os eixos centrais dessas articulações políticas estiveram (e ainda hoje estão) diretamente relacionados ao reconhecimento de suas diferenças frente aos processos de assimilação e integração empreendidos por esses Estados ao longo das relações de contato. Nas últimas décadas, tais processos se tornaram mais evidentes, passando a ser questionados por sujeitos e coletivos indígenas em um processo que denominamos de emergências políticas e sociais de sujeitos e coletivos indígenas na América Latina, os quais, informam os processos decoloniais. Nesse sentido, propomos uma análise histórica e política que se debruça sobre os movimentos indígenas ocorridos no Brasil e na Colômbia de
\end{abstract}

1 O presente artigo é fruto de duas comunicações apresentadas no XXIX Simpósio Nacional de História da ANPUH, ocorrido entre os dias 24 e 28 de julho de 2017, na Universidade de Brasília (UNB), no Distrito Federal, Brasil. Os autores consideraram oportuno desenvolvê-lo por perceberem a relevância das especificidades e correlações que informam articulações entre movimentos sociais indígenas ocorridos numa perspectiva geopolítica mais ampla que comporta a América Latina. Neste caso, apontam elementos para se pensar processos históricos característicos ocorridos no Brasil e na Colômbia a partir da segunda metade do século XX, os quais informam o protagonismo indígena decolonial de sujeitos e coletivos até então submetidos a relações de dominação social, política e econômica estatais.

2 Universidade Federal de Rondônia (UNIR), Porto Velho, Rondônia, Brasil.

3 Universidade Federal do Espírito Santo (UFES), Goiabeiras, Vitória, Espírito Santo, Brasil. 
modo a identificar, conhecer e debater sobre algumas de suas características singulares e correlacionais. A ênfase nos processos sócio-políticos que possibilitaram o reconhecimento constitucional da diversidade e da diferença de povos nesses dois países se torna elemento importante, no âmbito das reformas econômicas e neoliberais, para refletirmos sobre a ampliação da participação política de grupos sociais considerados incapazes de protagonizar a luta pela reivindicação das demandas mais elementares de seus modos de vida. Nesse sentido, o objetivo do texto é apresentar elementos históricos que permitam a reflexão sobre fenômenos de emergências políticas e sociais de povos indígenas, desencadeadas no Brasil e na Colômbia a partir da segunda metade do século XX.

Palavras-chave: movimentos indígenas contemporâneos; território; América Latina.

Abstract: In the context of a political and economic crisis that has materialized in several Latin American countries in the second half of the twentieth century, indigenous peoples have articulated particular strategies in the struggle for social rights in the legislations and institutions of states considered as national in a historical process of mobilizations and ethnic demands in the national and international scope. The central axes of these political articulations were (and still are today) directly related to the recognition of their differences in the processes of assimilation and integration undertaken by these states. In the last decades, these processes have become more evident, being questioned by ethnic groups and individuals in a process that we call political and social emergencies of indigenous subjects and collectives in Latin America. In this sense, we propose a historical and political analysis that focuses on the indigenous movements in Colombia and Brazil in order to identify, know and debate about some of their singular and correlational characteristics. The emphasis on socio-political processes that made possible the constitutional recognition of the diversity and difference of peoples in these two countries becomes an important element in the scope of economic-neoliberal reforms by broadening the political participation of social groups considered incapable of carrying out their most elementary demands. Thus, the purpose of this text is to present historical elements that allow a reflection on phenomena of political and social emergencies of indigenous collectives which occurred in Colombia and Brazil from the second half of the twentieth century.

Keywords: contemporary indigenous movements; territory; Latin America.

\section{INTRODUÇÃO}

Nelson Maldonado-Torres (2016, p. 88) observou que uma atitude decolonial "encontra suas raízes nos projetos insurgentes que resistem, questionam e 
Movimentos indígenas latino-americanos da segunda metade do século XX: reflexões comparativas sobre processos decoloniais no Brasil e na Colômbia

buscam mudar padrões coloniais do ser, do saber e do poder"4. Nesse sentido, a proposta deste texto é apresentar elementos que nos permitam refletir sobre como os movimentos indígenas ocorridos no Brasil e na Colômbia, a partir da segunda metade do século XX, além de apresentarem um paralelo, no que informa os acontecimentos envolvendo as emergências políticas e sociais de povos indígenas latino-americanos, nos permitem verificar como atitudes de natureza decolonial, empreendidas pelos povos indígenas desses dois países, indicam o protagonismo característico dos movimentos indígenas contemporâneos.

Iniciamos considerando que, dentre outros fenômenos de caráter político e social ocorridos na América no decorrer do século XX, os movimentos indígenas podem ser caracterizados como estratégias de transformação social de grande complexidade para estes sujeitos e suas coletividades, assim como para as políticas sociais e econômicas desenvolvidas nos territórios geopolíticos mais amplos que os circunscrevem. No México, por exemplo, o Congresso Indigenista Interamericano, ocorrido nos anos 1940, concorreu para a evidenciação de um debate que parecia estar longe de se constituir como a chave para a assimilação definitiva dos índios americanos pela modernidade. No Brasil, o Decreto-Lei n. 5.540, de 2 de julho de 1943 que declarava a data de 19 de abril como o "Dia do Índio" (BRASIL, 1943), apesar de mascarar sutis interesses do Estado Novo varguista (1937-1945) frente às pressões internacionais, abria precedentes para a problematização da presença indígena na formação e defesa das fronteiras nacionais e, como consequência, para a ampliação dos investimentos em projetos expansionistas como a "Marcha para o Oeste" (1937-1945)5 e a expedição

4 Uma excelente reflexão sobre a bibliografia que tem se desenvolvido sobre a questão decolonial na América Latina pode ser encontrada em Ballestrin (2013). Lacerda (2014) aponta questões importantes para se pensar as contribuições decoloniais dos movimentos indígenas na América Latina e a superação do mito "Estado-Nação".

5 Conforme indicado por Garfield (2000, p. 16), nas palavras de Getúlio Vargas, idealizador da Marcha para o Oeste, "a Marcha incorporou o verdadeiro sentido da brasilidade, uma solução para os infortúnios da nação". No entanto, para Thiago Leandro Vieira Cavalcante (2013, p. 158), empreendimentos como a criação da Colônia Agrícola Nacional de Dourados (CAND - 1943), a qual investiu seus esforços no esbulho dos territórios habitados pelos Guarani e Kaiowá, especialmente na região sul do estado do Mato Grosso, hoje Mato Grosso do Sul, resultaram em tentativas de desterritorialização que, ainda hoje, se refletem nos problemas enfrentados por esses grupos étnicos. Ainda conforme Cavalcante (2013, p. 163) "a colonialidade do poder do Estado brasileiro excluía os indígenas da nacionalidade brasileira, a qual eles integrariam somente quando deixassem de ser indígenas". Para Walter Guedes Silva (2016, p. 34) "para facilitar o controle e a exploração 
"Roncador-Xingu" (1943-1948)', as quais, conforme indicado por Seth Garfield (2000, p. 15-16), constituíram partes de um projeto dirigido pelo governo para "ocupar e desenvolver" o interior do Brasil como objetivo de um projeto civilizatório voltado, naquele período, para a região Centro-Oeste do país.

Como resultado, polêmicas concernentes ao recrudescimento das políticas de integração compulsória das populações indígenas no Brasil, desencadeadas a partir dos anos 1970, no contexto do Regime Civil-Militar (1964-1985), concorreram para emergências políticas e sociais de povos indígenas até então submetidos a relações de tutela do Estado Nacional. Conforme indicado por Eduardo Viveiros de Castro (2006), mas não somente, ${ }^{7}$ a tentativa de integração compulsória de sujeitos e coletivos indígenas, diante de um processo de homogeneização definitiva da sociedade brasileira concorreu para a evidenciação e reconhecimento jurídico da diversidade cultural existente no país.

Dito de outro modo, a atrapalhada política empreendida, no contexto do Regime Civil-Militar, em direção à emancipação compulsória dos povos indígenas,

do Sul do território Mato-Grossense, era necessário expropriar os índios de suas terras, o que se daria por meio da criação de Reservas Indígenas", as quais se constituíram, sutilmente, em alternativas legais de expropriação dos índios de seus territórios. Para Eva Maria Luiz Ferreira e Mariana Silva Falcão (2013, p. 99) "o Estado objetivava prestar assistência e proteção aos índios, promovendo, ao mesmo tempo, a sua passagem de categoria de índios para agricultores não índios. Para isso, na visão do SPI, era fundamental a criação de reservas indígenas que permitissem liberar o restante da terra tradicionalmente ocupada pelos índios para as frentes agrícolas". Por fim, conforme indicado pelo Pareceristas B deste artigo "Além disso, deve-se observar que o governo Vargas foi, para o bem e para o mal, um divisor de águas na história nacional, inclusive no que diz respeito à legislação indigenista, como verificado na Constituição de 1934, que trata das terras ocupadas por populações originárias e ainda hoje é usada no Judiciário para assegurar direitos territoriais de populações expulsas de seus territórios a partir de então". Assim, conforme se pode observar, e mesmo aprofundar, a partir da bibliografia indicada, diante das investidas do Estado Novo varguista, os Guarani e Kaiowá, mas não somente, protagonizaram lutas que ainda hoje informar que, apesar dos desafios e ameaças a seus territórios, a luta pela terra se constitui como elemento central dos movimentos indígenas contemporâneos não apenas no Brasil, mas na América Latina, como se verá no caso da Colômbia.

6 Conforme aponta Maria Eduarda Capanema Guerra Galvão (2011), um dos principais objetivos da Expedição Roncador-Xingu era o de estabelecer vias de comunicação pelo interior do Brasil até o Estado do Amazonas, além de "povoar" e explorar as regiões do centro-oeste brasileiro.

7 Desde, pelo menos, os anos 1950, conhecidos antropólogos brasileiros, tais como: Roberto Cardoso de Oliveira, Roberto DaMatta, João Pacheco de Oliveira, Antônio Carlos de Souza Lima e outros nomes do Museu Nacional da UFRJ, têm se debruçado sobre a discussão, podendo se constituir como importantes referências nacionais sobre a questão indígena e a luta pela emancipação política e sociocultural em território brasileiro. 
Movimentos indígenas latino-americanos da segunda metade do século XX: reflexões comparativas sobre processos decoloniais no Brasil e na Colômbia

resultou na evidenciação desses sujeitos no cenário nacional brasileiro. Se a intenção era retirar da tutela do Estado a responsabilidade pela defesa dos direitos indígenas, o resultado das agitações jurídicas e sociais malogradas foi, justamente, uma reação de caráter social, epistemológico e político em direção ao Estado contradizendo suas ações no que dizia respeito ao lugar dos sujeitos indígenas na comunidade brasileira (FERNANDES; COELHO, 2018).

Se considerarmos tais relações como parte de um processo histórico conflituoso e mesmo de um recente projeto social de caráter plurinacional, o qual informa a luta política de diferentes grupos étnicos na busca pelo reconhecimento da diversidade e da diferença, tendo em vista questões que movem relações sociais, redes de solidariedade e conexões entre direitos humanos, jurídicos e políticos observaremos que, na relação entre Estado e políticas sociais voltadas para os povos indígenas, o contexto atual não é de ganho significativo ou de comemoração geral, mesmo apesar de alguns ganhos e aparentes vitórias alcançadas desde o texto constitucional de 1988, no Brasil $^{8}$, e de 1991, na Colômbia.

8 Tais ganhos podem ser mais evidentes quando se analisa o caso brasileiro. Gersem José dos Santos Luciano- Baniwa (2006, p. 145), nos informa que o Brasil entrou na era da escolarização indígena e que iniciamos o século XXI com uma legislação forte se considerarmos as diretrizes educacionais voltadas para a questão da diversidade e da diferença. O autor, também observa que há, hoje em dia, leis bastante favoráveis a essas iniciativas indígenas, mas, na prática, "apresentam enormes distâncias, conflitos e contradições a serem superados". Lucia Fernanda Jófej Kaingáng (2006, p. 8) observou que "a consagração de princípios como o multiculturalismo e o pluralismo jurídico, pela Constituição de 1988, inaugura a era de interação horizontal entre os povos indígenas e a sociedade brasileira, agora norteada pelo reconhecimento dos indígenas como cidadãos brasileiros, em conformidade com o princípio da igualdade, mas sem prejuízo do reconhecimento à diversidade cultural dos povos autóctones estabelecidos pela Carta Magna". Marcos Terena (1982, p, 12) ao refletir sobre a importância da presença de sujeitos indígenas no Ensino Superior observou que "uma das tendências do paternalismo ocidental na formação do Índio de ontem era determinar até mesmo sua formação e seus compromissos com a instituição e com as comunidades. [...] o que era invisível por preconceito ou discriminação ao Índio Brasileiro, inclusive na formação educacional, faz nascer uma luz, um novo caminho que quer se somar na busca de novos ganhos como a ciência acadêmica ocidental, os recursos tecnológicos e os conceitos de formação acadêmica e científica". Para Daniel Munduruku (2012a, p. 116) os anos 1990, foram de ganhos significativos, inclusive no próprio movimento indígena brasileiro, pois, as lutas em defesa dos direitos indígenas possibilitaram um novo tipo de articulação que concorreu para uma nova conduta dentro do movimento, passando a aumentar a disposição para fazer acontecer as promessas que a constituição recém-aprovada fizera, "principalmente aquela que garantia que o governo iria demarcar todas as áreas indígenas num período de cinco anos, o que não aconteceria posteriormente". Joênia Batista de Carvalho - Wapixana (apud Araújo, 2006, p. 86-92), ao refletir sobre a questão das terras indígenas, observou que "não restam dúvidas de que a Constituição de 1988 trouxe significativos avanços em termos de 
O caso da Colômbia, reconhecida como Estado social de direito pluriétnico e pluricultural, nos anos 1990, também pode ser tomado como elucidativo de processos de emergência política e social ocorridos na América Latina. Edwin Cruz (2010) observou que o caso da Colômbia se demarca dentro dos discursos do multiculturalismo, diferente de países como Bolívia e Equador, onde se disseminou o conceito da plurinacionalidade ou Estado plurinacional. Para o autor, a diferença pode ter resultado do fato de a presença indígena ser muito maior no caso colombiano, resultando na possibilidade de criação de várias nacionalidades indígenas. Por esta razão, o presente texto se debruça sobre as análises dos movimentos indígenas ocorridos no Brasil e na Colômbia por considerar, além da similaridade nas discussões sobre o multiculturalismo, outras relações sócio-históricas comparativas, conforme se poderá perceber mais adiante.

Na América, mas não somente, os países em formação implementaram diferentes projetos no trato com as populações indígenas e seus territórios tradicionais. Foi assim que, desde o início da colonização europeia na América, foram desenvolvidos modelos assimilacionista que buscavam integrar os indígenas à civilização, destituindo-os dos direitos de viverem suas diferenças. A partir de meados do século XIX, os objetivos que fundamentavam tais projetos passaram a se relacionar diretamente às tentativas de dissolução de identidades diferenciadas e a constituição de nações homogêneas. Estas ideologias não toleravam a existência de modelos distintos de vida coletiva. Além de impor ao outro que vivesse em condições periféricas na estratificação social do modelo cultural dominante, tais projetos investiram na ideia de inserção através da integração de sujeitos e coletivos indígenas de forma subordinada no tecido das relações sociais regidas pelas leis do Estado?

conquista de garantias e direitos fundamentais [...] Apesar de a Constituição Brasileira reconhecer expressamente os direitos territoriais imprescindíveis à sobrevivência física e cultural dos povos indígenas, o exercício desses direitos é bloqueado por diversos fatores que demonstram a ausência e ineficiência de políticas públicas na proteção e na promoção daqueles que são fundamentais".

9 Alguns trabalhos podem auxiliar na análise dos projetos assimilacionistas, integracionistas e mesmo genocidas e etnocidas empreendidos pelo Estado desde os primeiros contatos com as populações indígenas no atual Estado brasileiro, podendo projetar reflexões que auxiliam na compreensão comparativa sobre como tais projetos foram desenvolvidos em regiões geopolíticas mais amplas que comportam o território brasileiro. Dentre eles, é possível mencionar: Luiz Felipe Baêta Neves (1976); Nádia Farage (1986); Stephen Grant Baines (1990); John Manuel 
Movimentos indígenas latino-americanos da segunda metade do século XX: reflexões comparativas sobre processos decoloniais no Brasil e na Colômbia

Na contrapartida dos projetos nacionalistas, o fundamento da necessidade de um Estado e uma cultura nacional e homogênea foi questionado por outras perspectivas e projetos sociais que nem sempre estiveram próximos dos centros de tomadas de decisões políticas. A partir da segunda metade do século XX, em vários países da América Latina. A diversidade étnica existente no seio dos Estados Nacionais em formação passou a questionar as estruturas políticas e sociais que fundamentavam os projetos integracionistas impetrados pelo Estado. A partir disso, foram formuladas, pelo menos, duas propostas que adquiriram especial importância nos discursos políticos e institucionais: o multiculturalismo ${ }^{10}$ e a interculturalidade ${ }^{11}$. No entanto, mesmo com articulações de caráter político que informam o protagonismo indígena contemporâneo, poucas coisas mudaram no que diz respeito a materialização dos direitos sociais reconhecidos constitucionalmente no Brasil e na Colômbia.

Monteiro (1994); Victor Leonard (1996); Sérgio Buarque de Holanda (1997); Francisco Jorge dos Santos (2002); João Pacheco de Oliveira e Carlos Augusto da Rocha Freire (2006); John Hemming (2007; 2009); Auxiliomar Silva Ugarte (2009); Rafael Chambouleyron (2010); Marcelo Piedrafita Iglesias (2010); Patrícia Melo Sampaio (2012); Maria Regina Celestino de Almeida (2003; 2013); Almir Diniz de Carvalho Júnior (2005; 2017) e Mauro Cezar Coelho (2005; 2017). Estes e muitos outros trabalhos podem nos informar sobre legislações e projetos indigenistas desenvolvidos com o propósito de subverter as práticas indígenas, assim como nos possibilitam reflexões sobre o protagonismo indígena desenvolvido historicamente nas relações de contato, estabelecidas com grupos não indígenas desde o período colonial. Por questões metodológicas, as pesquisas mencionadas nesta nota não constam nas referências finais deste texto.

${ }^{10}$ Quanto ao modelo multicultural, Cruz (2013) expõe que este teve seu início nos anos setenta, principalmente no Canadá, diante da coexistência de várias nações no interior do Estado. Foi o produto de uma posição contestadora dos movimentos sociais a respeito do projeto de integração nacional. Assim surge o modelo multicultural, pretendendo conciliar o modelo democrático e liberal com as exigências próprias da diversidade cultural.

${ }^{11}$ Para Walsh (2007, p. 57), a interculturalidade significa "o contato e intercâmbio entre culturas em termos equitativos; em condições de igualdade", ou, da mesma maneira, "um interpensamento e inter-relacionamento que não tem a pretensão de assumir a perspectiva do outros e sim de permitir que a diferença intervenha, abrindo assim novas perspectivas interculturais de viver 'com' ou 'con-viver'". As experiências do Equador e da Bolívia, por exemplo, são catalogadas como mostrar de um modelo intercultural que dá lugar a um Estado Plurinacional que tem, no conceito da autora, um marcado sentido político de refundação do Estado a partir de um constitucionalismo de baixo e formulado desde o Sul. A crítica intercultural concebe o multiculturalismo como mais uma estratégia de assimilação cultural que pretende colocar num mesmo nível as relações de poder entre culturas dominantes e subalternas. Desse modo, "por trás dos direitos étnicos assim reconhecidos se esconderia um propósito homogeneizador por parte do liberalismo, que os outorga como uma forma de fazer mais extensivos os seus princípios e formas de ver a vida" (WALSH, 2007, p. 55). 
Um dos dilemas mais evidentes no caso do Estado colombiano e que afeta as comunidades indígenas diretamente é o que tem a ver com os conflitos político-militares em seus territórios, os quais aumentaram exponencialmente no final do século XX e início do XXI. As exigências de um movimento indígena sobre sua propriedade coletiva e autonomia política e jurídica sobre este, estabelecem antagonismos com o governo neoliberal que privilegia os interesses do indivíduo e indicam uma abertura econômica em direção ao mercado. Conforme Houghton (2008), apesar do reconhecimento jurídico da condição de "resguardo", os territórios indígenas sofrem diferentes ameaças e não possuem a "proteção" que deveriam receber do Estado. É esta autonomia parcial o dilema que enfrentam os líderes das organizações indígenas, para os quais, o direito de território inalienável, imprescritível e não rentável não é respeitado.

Esta violência também influiu nas estratégias dos movimentos indígenas para proteger seus direitos. Houghton (2008) aponta que muitos líderes indígenas foram ameaçados, desaparecidos e assassinados nos últimos anos nas mãos de paramilitares, das guerrilhas e nas mãos do Estado. As invasões e ocupações armadas em territórios indígenas, resultando em cooptação e recrutamento de jovens indígenas e perturbando suas formas de vida, assim como a penetração de interesses econômicos, como a construção de hidrelétricas em grande escala; a exploração de hidrocarboníferos; extração de recursos madeireiros; instalação das monoculturas de plantação, como a palma africana ou a coca para o narcotráfico afetam, gravemente, os modos de vida e particularidades socioculturais de coletivos inteiros.

Muitos territórios indígenas vêm se tornando espaços de confinamento e desarraigo. Isso tem causado, dentre outras coisas, o deslocamento forçado de milhares de indígena aos centros urbanos. O marco de direitos formais que a Constituição Colombiana de 1991 supôs materializar, através da ampliação de políticas sociais relacionadas aos povos indígenas, está muito distante da realidade vivenciada pelos coletivos étnicos colombianos, especialmente no que se refere ao atendimento das necessidades básicas necessárias a manutenção de seus modos de vida.

A persistência de graves problemas como a usurpação de seus territórios por parte de colonos, proprietários de terra e narcotraficantes, soma-se à 
Movimentos indígenas latino-americanos da segunda metade do século XX: reflexões comparativas sobre processos decoloniais no Brasil e na Colômbia

implementação de projetos desenvolvimentistas por empresas extratoras de recursos naturais, as quais afetam significativamente o cotidiano desses coletivos e diminuem, cada vez, mais a qualidade dos nichos ecológicos que permitem suas sobrevivências, fazendo com que não se cubram as necessidades básicas como saúde, educação, alimentação e moradia. Tais questões, somados às agressões físicas e culturais permanentes, exercidas pelas instituições do Estado, da igreja e das missões religiosas internacionais, assim como dos colonos, proprietários de terra, narcotraficantes, guerrilha e exército ameaçam a sobrevivência, convertendo seus territórios em zonas de guerra e de conflito no marco de um Estado colombiano bipolar que orgulhosamente se nomeia multiétnico e pluricultural.

Foi contra todas essas práticas ainda existentes em solo colombiano que a década de 1990 foi testemunha do nascimento de um Estado multicultural, que surgiu no espírito otimista e esperançoso que marcou a Assembleia Nacional Constituinte. Mas, conforme observou, em 2001, Lorenzo Muelas, importante liderança indígena presente naquela Constituinte, esse otimismo do Movimento Indígena Colombiano se diluiu entre as leis de papel e a realidade da violência na Colômbia. No entanto, apesar das mazelas, o dilema da violência e das leis estruturou um movimento indígena que emergiu localmente e se fez visível a nível nacional, mesmo que, ao final do século XX, este mesmo movimento social pareça subordinado e desaparecido na cooptação e violência por parte dos atores armados, incluindo o próprio Estado colombiano.

No caso brasileiro, conforme apontou Eduardo Viveiros de Castro (2006), pelo menos dois fenômenos resultaram dos processos de emergências políticas e sociais desencadeados a partir da segunda metade do século XX. O primeiro deles foi o surgimento de diversos projetos pró-indígena em forma de associações e organizações não estatais como, por exemplo, as Comissões Pró-Índio (CPI), a Associação Nacional de Ação Indigenista (ANAÍ), o Centro de Trabalho Indigenista (CTI) e o Projeto Povos Indígenas no Brasil (PIB), o qual esteve na origem do Instituto Socioambiental (ISA). O segundo foi que, em reação às propostas emancipacionistas compulsórias que tomaram forma nos anos 1970 e 1980, surgiram as chamadas "etnias emergentes" como resposta contrária às expectativas do Estado.

Ao tratar do advento dos movimentos indígenas no Brasil, Poliene Soares dos Santos Bicalho (2010a) observou que as organizações e associações pró-indígenas, 
não devem ser ignoradas no processo de articulação desses movimentos, assim como não devem ser supervalorizadas. Estas foram condicionantes importantes naquela conjuntura e auxiliaram significativamente na organização dos movimentos indígenas. Assim, esta importância não deve ser negada. Ainda para a autora, a partir da década de 1970, vários encontros denominados de Assembleias Indígenas passaram a acontecer em todo o país. A cada assembleia, os povos indígenas fortaleciam articulações, conformando um longo processo que condicionaria de modo significativo os rumos que seriam tomados a partir dali. Nesse sentido, não se pode perder de vista o lugar que as organizações pró-indígenas ocupava e dos jogos de interesses maiores, nos quais estavam inseridas. Portanto, o lugar dessas organizações deve ser constantemente reavaliado à medida que os povos indígenas vão adquirindo a predominância nos processos de luta pelos seus direitos.

Nesse sentido, as organizações e associações pró-indígenas se constituíram como possibilidade de ampliação das redes de conexões entre grupos indígenas estabelecidos em diferentes regiões do país. A luta pelo reconhecimento da diversidade e da diferença foi importante para evidenciar um agente social que exercia sua atuação política, através de suas agências sem o direito ao reconhecimento de sua cidadania diferenciada. O exercício da cidadania parece ter se constituído como uma constante nos movimentos indígenas antes mesmo do reconhecimento constitucional de suas diferenças. Apesar de, na atualidade, presenciarmos a instalação de crises políticas que evidenciam os limites e possibilidades de sistemas políticos presidencialistas, como no caso do Brasil, os processos de emergência política e social que tomaram forma na América Latina, nos anos 1970 e 1980, concorreram para a criação das bases democráticas que sustentam as concepções de democracia existentes nesses países, nos quais, as agências indígenas foram exemplares e educativas da sociedade mais ampla de seus territórios geopolíticos.

$\mathrm{Na}$ sociedade latino-americana atual, onde sujeitos e coletivos indígenas lutam pelo reconhecimento da diversidade, da diferença, assim como políticas sociais que atendam suas especificidades socioculturais, as conquistas resultantes das históricas lutas dos movimentos sociais, especialmente indígenas, parecem carecer de uma nova investida contundente contra o Estado para que este seja pressionado a implementar políticas sociais relacionadas aos direitos conquistados por esses grupos em condições periféricas. As injustiças estão por todos os 
Movimentos indígenas latino-americanos da segunda metade do século XX: reflexões comparativas sobre processos decoloniais no Brasil e na Colômbia

lados e constituem processos de longa duração. Guerras de conquista, expulsão de comunidades inteiras de seus territórios, genocídios e etnocídios resultantes de políticas assimilacionistas constituem a base histórica dessas relações ${ }^{12}$.

Poderíamos dizer que mesmo após longos anos de articulações políticas, empreendidas por plurais movimentos indígenas na América Latina, especialmente a partir dos anos 1970, uma tempestuosa nuvem de preconceito e negligência ainda paira no ar. Desconhecimento, omissão e desrespeito às causas indígenas são características de parcelas significativas da sociedade, especialmente de alguns grupos que direcionam o país com suas decisões nos Congressos Nacionais. Apesar disso, processos de emergência política e social, desencadeados por diferentes povos indígenas nas últimas décadas, parecem evidenciar a continuidade de uma luta iniciada ainda nos primeiros contatos e que tem adquirindo novas roupagens a partir de estratégias contextuais de sobrevivência.

Com base nas questões apontadas até o momento, consideramos que este texto pode auxiliar em uma reflexão comparativa entre as emergências políticas e sociais de povos indígenas, estabelecendo relação entre os casos do Brasil e da Colômbia com base na constatação de um panorama internacional que aponta para as lutas e articulações dos movimentos indígenas ocorridos na América Latina. Para tanto, apresentaremos algumas reflexões que informam como determinados sujeitos e coletivos indígenas desenvolveram e articularam estratégias em âmbitos locais, regionais, nacionais e internacionais de modo a empreender uma série de lutas pelo reconhecimento da diversidade e da diferença de povos a partir de fenômenos de etnicidade. Esta proposta, no entanto, se limita a evidenciar os aspectos históricos mais gerais que informam a articulação política de determinados coletivos étnicos na relação que passaram a estabelecer com o Estado a partir de

\footnotetext{
${ }^{12}$ Além da bibliografia já citada na nota de rodapé número 6, podemos incluir o recente dossiê intitulado: Remoções forçadas de grupos indígenas no Brasil Republicano, publicado pela Revista Mediações, em 2017, e organizado pela professora Edilene Coffaci de Lima e pelo professor Jorge Eremites de Oliveira. O Dossiê contém uma série de artigos que tratam das políticas indigenistas pensadas para os povos indígenas, nas quais se incluem processos de remoções forçadas, empreendidas contra povos indígenas de diferentes regiões do Brasil, tratando, também, das denúncias feitas através do documento denominado Relatório Figueiredo, o qual foi resultado de uma CPI criado nos anos 1960 para investigar denúncias de atrocidades cometidas pelo então Serviço de Proteção aos Índios (SPI) (1910-1967). O Dossiê está disponível no site da Revista Mediações, podendo ser acessado através do endereço: http://www.uel.br/revistas/uel/index. $\mathrm{php} / \mathrm{mediacoes/issue/view/1419.}$
} 
características particulares que indicam o protagonismo indígena contemporâneo tornado manifesto nos textos constitucionais dos dois países aqui analisados.

\section{MOVIMENTOS INDÍGENAS NA COLÔMBIA}

A la constituyente llegamos después de un largo proceso de lucha en el que debimos enfrentar tanto al Estado como a los sectores de derecha e izquierda del país que se negaban a reconocer nuestra existencia y los derechos que tenemos. Por eso, es importante aclarar que nuestros logros en la constituyente no fueron un regalo del gobierno, allí solo recogimos lo que veníamos sembrando a costa de gran dolor, lagrimas, cárcel y muerte de muchos de nuestros mejores dirigentes. (Lorenzo Muelas Hurtado, liderança indígena, 2014, p. 44).

Historicamente, o Movimento Indígena Colombiano (MIC) e suas principais organizações indígenas, em perspectiva político-institucional, surgiram num contexto de defesa e luta pela terra, tendo como epicentro de suas articulações a região do Cauca, ao sul oriental colombiano, nos Andes, durante o período de formação da Frente Nacional (1958-1974) e por meio da disposição da Lei n. 135, de 1961, a qual buscou uma saída às problemáticas rurais através de uma reforma agrária da qual resultaram diversos conflitos locais e regionais pela propriedade e usufruto da terra (COLÔMBIA, 1991).

Conforme indicado por Alfredo Vazquez Carrizosa (1992), A Frente Nacional foi uma coalizão política estabelecida em 1958 entre o Partido Liberal e o Partido Conservador da República da Colômbia. Ela surgia, então, como uma resposta diante da chegada da ditadura militar, em 1953. A luta pelo poder, desencadeada entre os anos de 1954 e 1956 resultou em uma década de grandes índices de violência e enfrentamentos políticos radicais entre os partidos políticos colombianos. Foi então que Alberto Lleras Camargo, representante do Partido Liberal e Laureano Gómez Castro, do Partido Conservador, chegaram a um acordo ao reconhecerem a necessidade de um pacto entre os partidos com o objetivo restaurar o bipartidarismo no Estado. No dia 24 de julho de 1956, em terras espanholas, os líderes partidários assinaram o chamado Pacto de Benidorm, com base no qual, se estabeleceu um sistema de governo que, durante os 16 anos seguintes, fundamentou a manutenção do poder presidencial, o qual se alternaria a cada quatro anos entre um representante liberal e outro conservador. O Período denominado 
Movimentos indígenas latino-americanos da segunda metade do século XX: reflexões comparativas sobre processos decoloniais no Brasil e na Colômbia

Frente Nacionalista, o qual durou até 1974, significou uma espécie de "ditadura" feita pelos partidos mais tradicionais da Colômbia, perpetuando o clientelismo e a exclusão política naquele Estado (VAZQUEZ CARRIZOSA, 1992).

Apesar disso, conforme indicado por Archila e González Piñeros (2010), este contexto permitiu que em 1968 se constituísse a Asociación Nacional de Usuarios Campesinos (ANUC), a qual possibilitou que várias organizações, tanto camponesas como de sindicatos agrários, se estabelecessem num mesmo espaço de representação e atuação política. As articulações, ocorridas entre os campesinos, possibilitou às suas organizações caminhar em direção ao fortalecimento da luta pelo acesso à terra e melhores condições de trabalho para o campesinato colombiano.

Naquele contexto, a recuperação do direito ao usufruto da terra se converteu em tema central da luta indígena e camponesa. Ainda que no caso indígena esta luta remonte às ocupações e/ou retomadas de fazendas numa ação coletiva liderada por Manuel Quintín Lame e José Gonzalo Sánchez, importantes lideranças indígenas nas décadas de 1920 e 1930, na região chamada de O Grande Cauca. Além disso, na década de 1970, foi criado o Conselho Regional Indígena do Cauca (CRIC) como organização particularmente indígena, distanciando-se das organizações camponesas e operárias existentes até então. Ainda segundo Archila e González Piñeros (2010), a luta pela terra no Cauca, a qual ficou conhecida como "quintinadas", possibilitou o surgimento do MIC.

No começo dos anos 1970, com a emergência do CRIC e seu distanciamento das organizações camponesas, principalmente da ANUC, a luta pela terra foi impulsionada pela efervescência e ressurgimento de questões que relacionavam as territorialidades com as questões étnicas. Além disso, a identidade de classe, associada à luta camponesa e operária, fortaleceu os movimentos sociais na luta por direitos. Isso foi acompanhado pela denúncia de várias comunidades frente às constantes violências cometidas contra povos indígenas. As reivindicações e denúncias sobre a violação dos direitos humanos fez com que o movimento indígena alcançasse o contexto político internacional.

Para Caviedes (2007), as denúncias de violações dos direitos políticos e civis dos povos indígenas aumentam em 1978. As denúncias registradas na época, por meio da imprensa nacional, regional e local demonstraram que o autor central destas violações foi o Estado colombiano. Ainda que este pico, ocorrido 
em 1978, não tenha voltado a se repetir nos quatro anos seguintes, o número de denúncias feitas pelas organizações indígenas, entre os anos de 1979 e 1982, através do órgão que denunciava em nome das comunidades de todo o país, o Jornal Unidad Indígena, criado em 1974, a violência se manteve em quase o dobro da média dos anos anteriores a 1978. Para Archila e González Piñeros (2010), quando se apresenta este "despertar da luta indígena" desde o reconhecimento, ressignificação e autonomia étnica ${ }^{13}$, ou seja, além da preocupação com a recuperação da terra, se iniciou, então, uma mudança dentro do próprio movimento indígena colombiano. Este passou de uma posição de "classe" a uma posição de pertencimento desde o étnico.

Ainda segundo Archila e González Piñeros (2010), tais processos possibilitaram, às organizações indígenas emergentes posteriormente, nos anos de 1980, pensar na definição de identidades mais ligadas ao étnico e às suas próprias manifestações culturais. Na década de 1980 o MIC logrou se consolidar em um contexto histórico de repressão generalizada à mobilização social, baseado em um projeto político de unidade, interculturalidade e relações interétnicas pela defesa dos avanços feitos na década anterior (1970) em matéria de recuperação de terras e autonomia.

Andrade (2007), observou que, em outubro de 1980, na comunidade Lomas de Llarco do município de Coyaima, no estado de Tolima, se realizou o "Primeiro Encontro Nacional Indígena da Colômbia". Na assembleia geral daquele encontro, ficou definida a criação da "Coordenação Nacional Indígena da Colômbia", que teria como função a organização e convocação dos próximos congressos. Assim, em fevereiro de 1982, aconteceria o "Segundo Congresso Nacional Indígena", realizado em Bosa, no estado da Cundinamarca, onde foi fundada a Organização Nacional Indígena da Colômbia (ONIC), com a participação de 1.500 delegados de diversos grupos étnicos do país. A partir dali, a ONIC passou a se constituir como autoridade nacional de governo indígena na Colômbia.

Aqui, aproveitamos a ocasião para observar que a fundação da ONIC foi resultado de processos de reorganização e ampliação da autonomia do MIC,

\footnotetext{
${ }^{13}$ Aqui, autonomia, corresponde à ideia de exercer o governo próprio em seus territórios. A capacidade de administrar e organizar sua vida econômica e social de acordo com suas necessidades e padrões culturais, frente aos processos de integração da Nação colombiana (ANDRADE, 2007).
} 
Movimentos indígenas latino-americanos da segunda metade do século XX: reflexões comparativas sobre processos decoloniais no Brasil e na Colômbia

e iniciado pelo CRIC, modelo das organizações indígenas modernas na década de 1970. Assim se reuniram alguns líderes das organizações de diversos tipos e povos indígenas (Arhuaco, Kogui, Sikuani, Emberá, Cañamomo, Pijao, Pastos) e grupos étnicos amazônicos, com os indígenas caucanos (Nasa, Coconucos e Guambianos [Misak]). Estes líderes e vozeiros buscavam dar uma identidade mais sólida a diversas reivindicações, protegendo logros e demandas pela construção de territorialidades étnicas autônomas no Estado colombiano.

No início da década de 1990, começou a se visibilizar a construção de um sujeito político e social étnico na América Latina, com formas de fazer política, discursos e reivindicações próprias. Esta mobilização social étnica particularmente indígena, na Colômbia, teve sua origem nos anos de 1970 e a efervescência e consolidação de suas principais organizações nos anos 1980. Nos anos 1990, o significado destas mobilizações e da constituição de um movimento social indígena colombiano, com base em ações de caráter coletivo, empreendidas por determinados grupos étnicos - os quais tinham como centro de estratégia política a luta pela terra e autonomia - transformou-se na luta pelo reconhecimento da identidade étnica, a qual se constitui como base da solidariedade grupal e cultural dessas coletividades pela sobrevivência e coexistência com a diversidade e a diferença.

Conforme indicado por Bengoa (2000), este fenômeno de mobilização política indígena na Colômbia se expressou a partir de uma dinâmica da movimentação social na América Latina, mas, também, de estratégias de negociação, representação e pressão diante das mudanças econômicas e políticas dos Estados Latino-Americanos. Além disso, as relações com organismos ou organizações internacionais, também chamados de instituições multilaterais, se tornaram constantes.

A Convenção 169 da Organização Internacional do Trabalho (OIT), assinada em 1989, instituiu o reconhecimento da diferença e da diversidade que caracteriza os sujeitos e coletivos indígenas diante da normativa internacional. Desse modo, os indígenas passaram a ser reconhecidos, no âmbito jurídico internacional, como sujeitos de direitos, membros de uma comunidade nacional, e como sujeitos protagonistas das políticas sociais a eles relacionadas. Além disso, o texto da OIT 169 apontou para a necessidade de reconhecimento dos modos particulares dos coletivos indígenas no que indica as relações que estabelecem com o meio ambiente. Foram reconhecidos o direito ao território como elemento importante na 
manutenção de projetos de vida. Assim, a Convenção 169 da OIT possibilitou às organizações indígenas colombianas a ampliação de suas atuações políticas em espaços transnacionais, se constituindo como um dos principais atores político da segunda metade do século XX na América Latina. ${ }^{14}$

No início dos anos 1990, em um contexto internacional caracterizado pela ascensão da etnicidade e pelo surgimento de marcos teóricos que defendiam o direito à diferença, a democracia e os direitos das minorias sociais, além de um contexto político nacional em permanente crise de legitimidade que lutava pela participação política de outros setores sociais antes excluídos, como possibilidade para a "refundação" de um Estado social de direitos, o cenário político se tornou favorável às demandas de caráter étnico de sujeitos e coletivos indígenas. A participação na Assembleia Nacional Constituinte (ANC) de 1990, na qual foi expedida a Constituição Política de 1991 foi, talvez, o feito mais evidente, em âmbito nacional, do protagonismo político na história do Movimento Indígena Colombiano (MIC). Pela primeira vez na história da Colômbia, os dirigentes indígenas participaram da criação de uma constituinte ao liderar não só as demandas das comunidades e organizações indígenas, mas, também, a de outros setores étnicos, sociais e populares na Colômbia.

Os constituintes indígenas eleitos naquela ocasião foram: Lorenzo Muelas Hortado, da comunidade indígena caucana Misak; Francisco Rojas Birry, pertencente à comunidade Emberá, no pacífico colombiano e Alonzo Guzmán, representante do Movimento Armado Quintín Lame, recentemente desmobilizado. Desse modo, num contexto particular de abertura democrática e econômica do Estado,

${ }^{14}$ Cabe aqui uma observação: Há países, como o Brasil, que ratificaram a Convenção 169 da OIT, de modo que a referida Lei, de âmbito Internacional, passou a valer como lei interna de caráter infra ou supraconstituicional. Por outro lado, há países, como o Uruguai e a Guiana, para tomarmos como exemplo apenas a América Latina, que, até o momento, não ratificaram a Convenção 169 da OIT e, por consequência, não estão submetidos às deliberações a ela concernentes. Em matéria intitulada "300 anos depois, índios querem retomar o espaço perdido no Uruguai", publicada no dia 24 de outubro de 2017, pelo jornal El País, o jornalista Pablo Albarenga observou que de acordo com Martim Delgado Cultelli, diretor do Conselho da Nação Charrua (CONACHA), em uma entrevista transmitida pela Rádio Pedal, "o Governo Uruguaio não ratifica o acordo por duas razões: Pela tradição do Estado, construído com base em um genocídio caracterizado pela invisibilidade e negação dos povos indígenas e pela pressão dos sindicatos rurais em relação à devolução e demarcação territorial". Disponível em: https://brasil.elpais.com/brasil/2017/10/13/ internacional/1507902270_613238.html. Acesso em: 5 set. 2018. 
o MIC conseguiu dar continuidade à luta indígena. Mas, desta vez, no marco de uma constituinte considerada, por muitos, como carta de "salvação" para a crise de legitimidade do Estado colombiano.

Diante dessas considerações, podemos observar que a Constituição de 1991 resultou numa reconfiguração do Estado Nacional Colombiano, procedendo com, pelo menos, cinco mudanças significativas, a saber: 1. De um Estado de direito ao Estado social de direito; 2. Reconhecimento dos Povos Indígenas, enquanto sujeitos coletivos de direito; 3. Reconhecimento constitucional de um Estado multicultural e pluriétnico, a qual concorreu para a valorização de outras culturas e de caracterizações distintas acerca da propriedade, da família, da religião, da saúde e da natureza, entre outros; 4. Obrigação estatal de oferecer aos indígenas um tratamento diferenciado que potencialize suas diferenças, etnicidades e culturas e 5. Ação de tutela que, na perspectiva constitucional colombiana, atua como nova ferramenta jurídica no intuito de proteger os direitos fundamentais dos indígenas, enquanto indivíduos e povos (COLÔMBIA, 1991). Tais processos, a nosso ver, abrem precedentes para estabelecermos uma análise comparativa com os processos de emergências políticas e sociais de povos indígenas, ocorridas no Brasil, a partir da segunda metade do século XX.

\section{MOVIMENTOS INDÍGENAS NO BRASIL}

No Brasil, de fato existe desde a década de 1970, o que podemos chamar de movimento indígena brasileiro, ou seja, um esforço conjunto e articulado de lideranças, povos e organizações indígenas em volta de uma agenda comum de luta, como é a agenda pela terra, saúde, educação e outros direitos. Foi esse movimento indígena articulado, apoiado por seus aliados, que conseguiu convencer a sociedade brasileira e o Congresso Nacional Constituinte a aprovar, em 1988, os avançados direitos indígenas na atual Constituição Federal. (Gersem Baniwa, liderança indígena, 2007).

Quando pudermos considerar o passado dos povos indígenas com seus métodos de sobrevivência e suas experiências como orientação para melhorar o futuro do índio, saberemos então que os caminhos traçados de acordo com o pensamento do índio também estão voltados para o sentimento de brasilidade e expressam preocupação com as coisas do Brasil. (Marcos Terena - União das Nações Indígenas, 1981). 
A Constituição Brasileira de 1988 foi escrita e promulgada sob a sombra nefasta de um regime civil-militar que sistematicamente violou direitos elementares da população nacional, incluindo os povos indígenas. Apesar disso reflete, em parte, a luta política dos diferentes grupos sociais existentes no país, nos quais se incluem os coletivos étnicos. Também atua como marco importante na luta pela ampliação de políticas sociais que atendam as demandas das rotuladas "minorias", as quais, ao contrário, constituem, inquestionavelmente, a maior parcela da sociedade brasileira.

Havia, no entanto, um contexto político favorável ao surgimento do que se convencionou chamar de a Constituição da Cidadania. Dentre as principais mudanças trazidas por sua promulgação, podemos indicar, pelo menos sete, a saber: 1. Ampliação das liberdades civis e individuais; 2. Retomada das Eleições Diretas; 3 . Fim jurídico da censura à imprensa; 4. Direito de voto aos analfabetos; 5. Ampliação dos direitos trabalhistas; 6. Reforma do sistema tributário e 7. 0 respeito à diversidade e diferença de povos indígenas, reconhecendo, pelo menos em caráter jurídico, o multiculturalismo no Brasil (BRASIL, 1988) ${ }^{15}$. No entanto, tais ganhos constitucionais não resultaram apenas daquilo que poderíamos denominar de "boa vontade" dos constituintes, mas, especialmente das lutas políticas travadas por uma série de articulações indígenas que tomaram maiores projeções a partir dos anos 1970.

No Brasil, os povos indígenas passaram a se articular politicamente na defesa de direitos sociais (relacionados à questão da terra, saúde, saneamento básico e educação), bem como desenvolveram processos de emergências étnicas ${ }^{16}$, a

${ }^{15}$ Conforme consta no Artigo 132 da Constituição Brasileira, "São reconhecidos aos índios sua organização social, costumes, línguas, crenças e tradições, e os direitos originários sobre as terras que tradicionalmente ocupam, competindo à União demarcá-las, proteger e fazer respeitar todos os seus bens" (BRASIL, 1988).

${ }^{16}$ Aqui, tomamos como base de análise os processos denominados por Fernandes (2018) de cidadanização. Para o autor, conforme se verá mais adiante, este conceito histórico implica uma análise que informa processos de emergências primeiramente políticas, por determinados grupos étnicos, ao desenvolverem organizações de caráter reivindicativo perante o Estado a partir dos anos 1970, através da criação de associações e organizações indígenas auxiliadas por setores pró-indígenas da sociedade civil, nos quais podemos citar o Conselho Indigenista Missionário CIMI, como um dos principais articuladores, auxiliando naquilo que se passou a denominar de Assembleias Indígenas. O segundo momento, o qual denominamos de emergências sociais, está relacionado com o reconhecimento constitucional da diferença e diversidade de povos existentes no Brasil, concorrendo para a criação de políticas sociais que considerem as diferen- 
Movimentos indígenas latino-americanos da segunda metade do século XX: reflexões comparativas sobre processos decoloniais no Brasil e na Colômbia

partir das emergências políticas, mas, também, do fortalecimento de propostas educacionais diferenciadas. Assim, as lutas dos movimentos indígenas resultaram no reconhecimento jurídico de suas diferenças, através do texto constitucional de 1988 e na ampliação das lutas por uma formação educacional específica e diferenciada, as quais se tornaram mais evidentes a partir de 1990.

Juntamente aos processos de autodeterminação, iniciados a partir da década de 1970, os diferentes grupos étnicos passaram a fortalecer movimentos relacionados à criação de políticas educacionais específicas. Após a promulgação do Decreto n. 26/91, que passou a responsabilidade sobre a educação escolar indígena do órgão da FUNAI para o Ministério da Educação e Desporto (BRASIL, 1991), os mecanismos e políticas educacionais relacionados aos indígenas se fortaleceram institucionalmente, em especial, por conta das articulações políticas empreendidas pelos Movimentos de Professores Indígenas. Mais recentemente, os Movimentos Indígenas passaram a se posicionar estrategicamente na luta pelo acesso ao Ensino Superior diferenciado sem, no entanto, desarticular a luta política pelo direito ao reconhecimento e manutenção de seus territórios tradicionais.

Os processos que concorreram para as emergências de caráter político e social dos povos indígenas na Região Norte do país, por exemplo, resultaram de

ças e diversidades de povos existentes no país. Além disso, a escolha do termo "emergências étnicas" não se resume ao modo como este processo é entendido por sujeitos e coletivos indígenas, mas se amplia para uma dimensão analítica que procura também considerar como tais processos são parte daquilo que Frederik Barth (apud POUTIGNAT; STREIFF-FENART, 2011 [1969]) convencionou chamar de sociedade englobante. Assim, consideramos que o conceito de resistência, muito utilizado por pesquisadores da temática, também não é suficiente para dar conta de determinadas ações empreendidas por sujeitos e coletivos indígenas, especialmente no que diz respeito às relações políticas que passam a estabelecer com o Estado a partir dos anos 1970. Consideramos que existe uma dimensão do protagonismo indígena que está para além da concepção de resistência, o qual, estabelecendo uma relação com a Terceira Lei de Newton, com base nos princípios de ação e reação, é entendida, por muitos, apenas como uma resposta aos estímulos resultantes das políticas indigenistas desenvolvidas pelo Estado ao longo dos processos de contato. Entendemos que o que ocorre a partir da segunda metade do século XX são um conjunto de ações indígenas que informam estratégias até então não utilizadas por sujeitos e coletivos indígenas, as quais, indicam processos de emergências políticas e sociais que caracterizam aquilo que se tem denominado, não somente no Brasil, mas, na América Latina, de "decolonialidade" ou "descolonização" do ser do agir e do saber, conforme indicado por Luciana Ballestrin (2013) e Nelson Maldonado-Torres (2016). Nesse sentido, consideramos a utilização do termo agências indígenas para dar conta de um protagonismo que não se resume às ações empreendidas por estímulos exógenos, mas, informa novas atitudes protagonizadas por sujeitos e coletivos indígenas a partir da segunda metade do século XX e que procura dar conta das especificidades dessas ações, em caráter mais amplo, ocorridas no Brasil. 
demandas específicas que dizem respeito à processos históricos característicos dos povos indígenas da Amazônia Brasileira. Tais processos se iniciaram conjuntamente ao processo de autodeterminação e cidadanização $0^{17}$ dos sujeitos indígenas (FERNANDES, 2018). Assim, no caso brasileiro, consideramos que o acesso de sujeitos indígenas ao Ensino Superior tem relação com a questão da terra e a necessidade de se apropriar de mecanismos políticos e científicos na tentativa de acessar ferramentas estratégicas para auxiliar na luta em defesa de direitos constitucionais e nos processos de manutenção e fortalecimento étnicos. Tais processos constituem parte de um fenômeno de emergência política e social iniciado nos anos 1970 e aponta para características particulares do caso brasileiro.

Entre os anos 1970 e 1980, a Fundação Nacional do Índio (FUNAI), criada em 1967, e o Governo Civil-Militar (1964-1985) sofreram duras críticas de diferentes setores sociais. Este período foi marcado por intensas transformações políticas que resultaram da articulação de grupos de interesse que nem sempre se posicionaram nas estratificações hegemônicas da sociedade brasileira. Associações e organizações indígenas e pró-indígenas se articularam de forma estratégica diante de propostas que defendiam a assimilação dos povos indígenas com base em projetos estatais de homogeneização da sociedade brasileira ${ }^{18}$.

Conforme apontaram Fernandes e Coelho (2018), as discussões relacionadas aos binômios tutelado/emancipado e integrado/não integrado se mostraram incompatíveis com as práticas empreendidas historicamente pelos sujeitos indígenas. Diante do regime de exceção característico daquele período, dentre as finalidades dos discursos em jogo se incluía a modificação do Estatuto do Índio (1973), legislação indigenista de caráter profundamente tutelar. Apesar disso, esta iniciativa, por parte do Estado, estava diretamente conectada com

\footnotetext{
${ }^{17}$ Conforme apontou Fernandes (2018), a ideia de cidadanização pode ser pensada como um processo a partir do qual as relações entre Estado, políticas sociais e cidadania passaram a operar sob novos significados à medida que os movimentos sociais passaram a indicar que tanto o Estado, quanto as políticas sociais implementadas pelos governos deveriam ser pensadas como elementos a serviço da democracia, instaurando uma compreensão de que o cidadão seria, então, o agente central de todo o processo estatal.

18 Também neste caso, o recente dossiê intitulado: Remoções forçadas de grupos indígenas no Brasil Republicano, publicado pela Revista Mediações, em 2017, e organizado pela professora Edilene Coffaci de Lima e pelo professor Jorge Eremites de Oliveira, podem se constituir como importante material para uma compreensão sobre o impacto do Relatório Figueiredo para a extinção do SPI e a criação da FUNAI, em 1967.
} 
Movimentos indígenas latino-americanos da segunda metade do século XX: reflexões comparativas sobre processos decoloniais no Brasil e na Colômbia

interesses liberal-capitalistas baseados em projetos desenvolvimentistas que descaradamente agravavam a situação de coletivos indígenas estabelecidos em território nacional. O pretexto utilizado pelos representantes do Estado era de que tal legislação não atendia os interesses dos grupos indígenas. Más na visão de antropólogos, professores universitários, missionários, juristas, algumas lideranças indígenas, como Mário Juruna e Macus Terena, dentre outros o Estatuto do Índio (1973) não dava conta, na verdade, era do atendimento das demandas de grandes grupos empresariais interessados nas terras e na mão de obra indígena para o fortalecimento do capitalismo internacional ${ }^{19}$.

Naquele contexto, a desapropriação sutil das terras indígenas foi mascarada por propostas de emancipações compulsórias coletivas. Para os indígenas era necessário haver uma transformação no sentido atribuído à FUNAI. Esta deveria passar a atuar como um mecanismo de representação indígena perante o Estado e não como instrumento de assimilação dos povos indígenas, objetivo para o qual havia sido criada. Por conta de suas contradições, o Estatuto do Índio (1973) acabou sendo utilizado como justificativa para a criação de propostas assimilacionistas que propunham a derrocada derradeira das culturas indígenas. Más, houveram resistências e agências diante do indigenismo do Estado.

Mário Juruna, por exemplo, destacada liderança indígena Xavante (grupo étnico estabelecido na região Centro-Oeste do país), conhecido através da imprensa dos anos 1970 e 1980, conforme destacado por Graham (2011), atuou de modo particular em defesa das terras indígenas. Reconhecido como o único deputado federal indígena até a legislatura que termina no ano de 2018, Juruna já afirmava, em 1981, que a FUNAI não via os índios como pessoas, como adultos. Aliás, na sua concepção, ninguém via os índios como adultos. A própria FUNAI, responsável pela defesa dos direitos indígenas era, conforme Juruna, uma das principais responsáveis pelos desvios da Lei. Isto ocorria não somente por ser condescendente com práticas ilícitas cometidas contra os povos indígenas, mas, principalmente por se omitir do auxílio político que deveria fortalecer as lutas indígenas na defesa de suas demandas. Nas palavras de Juruna, "a Funai pode cumprir sua obrigação aplicando melhor o Estatuto do Índio e não passar por cima e fazer ameaças ao índio com o Estatuto" (COMISSÃO PRÓ-ÍNDIO, 1982, p. 23).

19 Para um aprofundamento da discussão, conferir: Becker, Souza e Oliveira (2013). 
Juruna, que entre 1983 e 1987 atuou como um dos Deputados Federais mais conhecidos do país, questionava as práticas empreendidas pela FUNAI de modo a forçar seus funcionários a refletir sobre os fundamentos daquela instituição. Assim, protestava:

Porque a Funai chama de agitador quem defende o índio? Então nós podemos chamar a Funai de traidora. $\mathbf{O}$ próprio Estado tem que reconhecer o índio como brasileiro porque ninguém tem mais direito do que nós. (COMISSÃO PRÓ-ÍNDIO, 1982, p. 23).

Para muitos líderes indígenas, como Mário Juruna, que iniciaram na década de 1970 o processo de articulação entre povos indígenas de diferentes regiões do país, o direito à cidadania brasileira não deveria se conformar pelas políticas emancipacionistas ou civilizatórias empreendidas pelo Estado, mas, a partir da lógica dos próprios indígenas. Para estes, a integração junto à comunidade nacional deveria ocorrer em seus próprios termos.

Aqui, para uma melhor compreensão das discussões desenvolvidas naquele período, consideramos importante observar que a ideia de integração deve ser pensada a partir de uma disposição criada pela comunidade envolvente como uma categoria que permitiu classificar, dentro de certos padrões, num jogo de escalas, o grau de assimilação dos sujeitos indígenas. O antropólogo Darcy Ribeiro, ex-Chefe da Casa Civil do Governo João Goulart e ex-Reitor da Universidade de Brasília (UnB), parece ter sido o primeiro a estabelecer categorias classificatórias sobre a condição dos indígenas nas suas relações com a comunidade envolvente. Ribeiro (1982 [1970]) criou uma classificação para os grupos indígenas, cunhando os termos: grupos isolados, grupos em contato intermitente ou permanente $e$ grupos integrados. Estes últimos, para Ribeiro seriam grupos articulados com a esfera econômica e institucional da nova sociedade brasileira.

Manuela Carneiro da Cunha (1985) observou que a noção de integrado, defendida por Ribeiro (1982 [1970]), foi apropriada de forma equivocada pelos redatores do Estatuto do Índio (1973) e pelos defensores dos projetos emancipacionistas. Para Cunha (1985), as classificações feitas por Ribeiro (1982 [1970]) se referem à coletivos indígenas, ou seja, a grupos étnicos e não aos sujeitos que os compõem individualmente. Outra questão é que a noção de integração defendida por Ribeiro se conformaria na articulação econômica e institucional com a 
Movimentos indígenas latino-americanos da segunda metade do século XX: reflexões comparativas sobre processos decoloniais no Brasil e na Colômbia

sociedade envolvente, não se constituindo, portanto, como uma descaracterização étnica por consequência do contato e interação com a comunidade não indígena.

Conforme apontou João Pacheco de Oliveira (1985, p. 25), a condição de índio era vista, pelo Estado, como transitória, "um estágio na caminhada civilizatória do estado de 'isolados' até aquele de integrado, (quando então cessariam os efeitos da tutela, ainda que persistissem alguns costumes e valores da tradição tribal)". Conforme o Estatuto do Índio (1973), ao atingir certo nível de integração, os indígenas poderiam ser emancipados do órgão tutelar (FUNAI), desde que solicitassem esse procedimento oficialmente do próprio órgão, através de requerimento específico para pedido de emancipação (BRASIL, 1973).

As considerações feitas pelos indígenas e o contexto de discussão sobre a questão da emancipação evidenciavam, no Brasil, um ponto importante: os povos indígenas precisavam articular novas agências que Ihes permitissem dialogar com o Estado se apropriando da lógica desenvolvida por ele. A emergência política, nestes termos, apresentou-se como uma estratégia particular naquela conjuntura de crise política, decorrente da instauração de um regime autoritário e de exceção. Os povos indígenas pareciam ter a seu favor uma série de mecanismos que poderiam utilizar para potencializar suas ações. Dentre eles, podemos destacar as associações e organizações pró-indígenas, mídias impressas e televisivas, como a novela Aritana (1978) que, apesar das fantasias literárias, indicava uma problemática contextual da sociedade brasileira e, especialmente, problematizava em seus roteiros um processo de articulação de luta pela terra que se desenvolvia em caráter regional e nacional, conectando diferentes povos indígenas de modo a lhes permitir certo alinhamento na reivindicação de suas demandas, especialmente na luta pela terra.

O contexto era de crítica geral ao Regime Civil-Militar no Brasil. Diferentes grupos sociais reivindicavam liberdade política, direitos sociais e trabalhista, liberdade de gênero, dentre outros. Obviamente que, para defender seus direitos, as lideranças indígenas precisavam dialogar com a comunidade envolvente. No entanto, abrir mão de suas diferenças para serem assimilados não parecer ter sido a intenção dos povos indígenas que passaram a ascender politicamente naquele contexto. A ideia de integração à comunidade nacional foi entendida pelos sujeitos e coletivos indígenas em seus próprios termos. A experiência de algumas 
lideranças indígenas junto à comunidade envolvente lhes permitiu a apropriação de conhecimentos que Ihes possibilitaram iniciar determinadas emergências políticas e sociais.

Em perspectiva nacional, o Brasil passava por intensas agitações políticas e sociais. Democracia, Cidadania e Direitos Humanos eram temas que estavam na pauta de primeira ordem nas agendas dos movimentos sociais. Nos anos 1980, a luta pela abertura política acompanhava manifestações pela criação de uma Constituição de caráter profundamente democrático para o novo governo. Os movimentos indígenas não estavam alheios a essas mudanças. A promulgação da Constituição Brasileira de 1988 reconhecia os esforços de uma série de lutas, manifestações, articulações políticas e sociais que levaram, pelo menos, duas décadas para se consolidar como pauta política.

Poliene Soares dos Santos Bicalho (2010), ao analisar os movimentos indígenas ocorridos no Brasil, entre os anos de 1970 e 2009, observou que a luta pelo reconhecimento e a garantia dos direitos indígenas tornou-se mais evidente durante os trabalhos da Assembleia Nacional Constituinte, em 1987. As articulações desenvolvidas pelos movimentos indígenas dimensionaram suas participações no texto constitucional20. Para além dos movimentos sociais de caráter urbano, "minorias étnicas", como os povos indígenas residentes nos sertões do Brasil, declaravam suas insatisfações pelo não reconhecimento de seus direitos políticos e sociais relacionados à questão da terra, saúde, saneamento básico e educação. O Brasil passava por momentos de intensas agitações políticas e sociais. A Constituinte de 1988 parece resultar de ambos processos, indicando um aspecto elementar daquele momento de efervescência política.

Os indícios nos levam a crer que muitas lideranças indígenas estavam se articulando com associações e organizações indígenas e pró-indígenas que thes possibilitassem a ascensão política necessária à reivindicação, manutenção e conquista de direitos para suas comunidades. Os resultados dessas emergências

\footnotetext{
${ }^{20}$ Bicalho (2010, p. 11) também observou que "o desfecho positivo desses trabalhos, quanto aos direitos indígenas, contribuiu para que a atuação destes povos como protagonistas de sua própria história se apresente na atualidade como especificidade do Movimento, experienciada em diferentes aspectos: organizações indígenas; representatividade das lideranças; elaboração de projetos e políticas públicas; diálogo mais direto com diferentes instâncias do Estado e da sociedade civil, entre outros".
} 
políticas se refletiram em outras demandas que passarão a tomar forma na década de 1980. A caminhada não foi, nem de longe fácil, assim como não passaria a ser a partir de 1988. As lutas permaneceriam, agregando demandas mais específicas, como o direito à educação escolar diferenciada, a qual se tornou mais evidente a partir dos anos 1990, e o acesso diferenciado de sujeitos indígenas ao Ensino Superior, tornado mais evidente a partir dos anos 2000. No entanto, tais demandas jamais se desviaram da luta pela terra, nem do direito de viverem suas diferenças e especificidades.

Assim, à luz da Constituição Federal de 1988, a integração, ou melhor, a interação dos povos indígenas, passou a ser reconhecida a estes como a capacidade de exercício da cidadania no "mundo dos brancos". Na atualidade, sujeitos e coletivos indígenas caminham em direção a materialização de políticas sociais que considerem suas diversidades e diferenças, assim como mantém a luta pela terra, saúde e educação, não necessariamente nessa ordem. Desse modo, no Brasil, as articulações do que Gersem Baniwa (2018) ${ }^{21}$ denominou de um Movimento PanIndígena Brasileiro, teve suas bases conformadas através de longos processos que evidenciam as agências do protagonismo indígena contemporâneo.

\section{EMERGÊNCIAS POLÍTICAS E SOCIAIS DE GRUPOS ÉTNICOS NA AMÉRICA LATINA}

Como assinalou Aníbal Quijano (2000), a crise do desenvolvimentismo, com a desintegração da estrutura produtiva e, consequentemente, das identidades camponesas e de classe que este promovia, significou uma revalorização de identidades étnicas que nunca se dissolveram completamente. A globalização, com seu novo universo de comunicação e virtualidade, possibilitou que as comunidades indígenas rurais antes isoladas, em meio à crise das identidades de classe, pudessem se conectar com outros sujeitos e coletivos indígenas estabelecidos em diferentes partes do continente. Tais conexões possibilitaram a estes sujeitos e coletivos se reconhecerem como parte de um processo histórico comum que os enquadrou em estruturas sociais de subordinação e dominação à lógica colonialista e imperialista.

${ }^{21}$ Entrevista concedida por Gersem José dos Santos Luciano - Baniwa, na Universidade Federal do Amazonas, em Manaus, no 29 de agosto de 2018. 
No caso colombiano, a correspondente crise da esquerda favoreceu ainda mais a destruição desta memória e desta identidade como percussores da ação política (QUIJANO, 2001). Por conta disso, não se pode desconsiderar a influência da dupla transição na região: tanto de regimes autoritários como de uma economia desenvolvimentistas limitada ao modelo neoliberal capitalista. Assim, a América Latina passou a se constituir como espaço de emergência das "novas etnicidades" que se caracterizaram pelo uso estratégico e mesmo reinvenção de etnicidades, base dos processos decoloniais aqui evidenciados.

Como indicado por Eduardo Restrepo (2004), em sua cartografia sobre as teorias e definições teóricas do conceito de etnicidade, os projetos que se fundamentam em tais perspectivas caminham numa direção relacional e não ontológica da categoria etnicidade, a qual foi construída no e pelo movimento indígena colombiano, especificamente expresso em suas organizações. Nas palavras de Restrepo (2004, p. 17), a etnicidade estaria

[...] asociada a un ejercicio de definición de categorías étnicas desde una posición relacional. [...] la etnicidad implica un encuadre relacional de identidad y diferencia más que la manifestación de un inmanente ser biológico o cultural... Esta tendencia aborda la etnicidad como un fenómeno intersubjetivo con efectos en las relaciones y prácticas sociales; es entendida, además, como un hecho objetivo que existe en el mundo exterior, independientemente de las categorías analíticas de quien la estudia. En general esta tendencia se asocia al formalismo y, en algunos casos, al estructuralismo.

No contexto dos movimentos indígenas da Colômbia e, especificamente no período que abarca o processo de formação e consolidação do Estado, poderíamos representar a etnicidade pelas ações desenvolvidas por distintos povos indígenas através de estratégias políticas que fundamentaram a luta diante da questão da territorialidade com base na evidenciação da diversidade e diferença que caracteriza e legitima as necessidades básicas de manutenção diferenciada de suas sobrevivências. Além disso, a territorialidade se tornou o espaço de produção e reprodução da vida e da luta pela sobrevivência diante do Estado. Assim, historicamente, mesmo apesar da materialização de complexos projetos de integração e assimilação dos coletivos indígenas diante de um processo de homogeneização social, a diferença e diversidade que dá forma a toda sociedade e suas relações 
Movimentos indígenas latino-americanos da segunda metade do século XX: reflexões comparativas sobre processos decoloniais no Brasil e na Colômbia

sociais, se tornou parte das relações, muitas vezes conflituosas, desenvolvidas entre indígenas e não indígenas no contexto latino-americano.

Considerando que a ação dos povos indígenas tem por consequência processos que dizem respeito ao âmbito interno e externo de suas comunidades, é salutar observar que, além de fortalecer a luta pelo reconhecimento de suas diferenças, a etnicidade fomentou a manutenção dos componentes que conformam as características identitárias de diferentes povos indígenas. Por conta disso, entendemos que o movimento interno (decorrente do impacto consequente da interação com outros grupos), bem como a seleção e apropriação de mecanismos externos que influenciam na manutenção da organização interna dos grupos indígenas, foram e ainda podem ser consideradas como operações condicionadas pelas etnicidades. Ou seja, a relação estabelecida entre grupos indígenas e não indígenas tende a modificar modos de vida e de organização dessas sociedades em contanto sem, no entanto, incorrer em processos de assimilação, aculturação ou extinção.

Considerando o que aponta Frederick Barth (2011), a relação entre diferentes grupos étnicos acaba mesmo é por evidenciar as diferenças e possibilitar uma relação de associação, seleção e diferenciação num imbricado jogo de interações culturais. Tais processos concorrem para a manutenção da consciência dos sujeitos que operam a partir de cosmologias distintas na manutenção de suas tradições, e na fundamentação dos argumentos necessários à luta pelo reconhecimento de suas diferenças frente à comunidade englobante. Desta forma, a etnicidade é, também, resultado da própria interação de grupos com características culturais diferentes. Tais relações criam um ambiente favorável à evidenciação de distinções étnicas. Para Barth (2011), "as distinções de categorias étnicas não dependem de uma ausência de mobilidade, contato e informação", pois, é na interação que se evidenciam as distinções e se desenvolvem as múltiplas estratégias de interação, associação ou rejeição das práticas culturais do outro. Assim, a interação entre os povos indígenas e a comunidade envolvente é exemplo elucidativo dos procedimentos de etnicidade ocorridos ao longo da história latino-americana.

No caso que informa as emergências políticas e sociais dos povos indígenas no contexto histórico da América Latina, na segunda metade do século XX, e a luta pelo acesso ao ensino superior como estratégia de fortalecimento da luta pela 
conquista de direitos relacionados à territorialidade, no caso do Brasil, o fator primordial que conecta os diferentes sujeitos é a agência indígena a partir da atuação política dos múltiplos protagonistas que, representados pelos movimentos étnicos, constituem a base das emergências políticas e sociais iniciada nos anos 1970, aliada à manutenção das tradições e reconhecimento de suas territorialidades e, nos últimos anos, ao acesso cada vez maior no âmbito do ensino superior de modo a fortalecer a luta pela defesa, manutenção e conquista de direitos, instaurando um processo de descolonização do pensamento nos termos apresentados por Maldonado-Torres (2016), Luciana Ballestrin (2013) e Lacerda (2014).

\section{CONSIDERAÇÕES PONTUAIS}

Os processos de emergência política e social de povos indígenas ocorridos no Brasil e na Colômbia a partir da segunda metade do século XX e expressos nos textos constitucionais de ambos países, informam processos particulares de articulação política de sujeitos e coletivos indígenas na América Latina. Apesar das relações históricas colonialistas que conectam tais processos, cada fenômeno deve ser analisado de modo relacional e específico, já que apresentam elementos particulares em suas estruturais, sociais, políticas e econômicas. Os apontamentos desenvolvidos neste texto fazem parte de duas pesquisas ainda em curso e apontam para reflexões iniciais que discutem a natureza das emergências políticas e sociais de coletivos indígenas. De todo modo, atualmente, a análise destes processos ocorridos na Colômbia e no Brasil nos permitem refletir sobre evidencias que nos informam um paralelo.

As estratégias políticas indígenas e indigenistas mencionadas neste texto fazem parte do longo processo histórico do contato entre grupos indígenas e não indígenas. Por esta razão, cabe aqui a observação de que, durante toda a história da América Latina, os coletivos indígenas resistiram como puderam ao genocídio, etnocídio e assimilação de suas tradições. A cada resistência, novas formas de opressão foram sendo criadas para extinguir povos indígenas. Considerando as especificidades de cada tempo e lugar histórico, parece-nos que, pelo menos, duas características estiveram presentes na relação entre índios e não índios: A primeira delas seria a relação desigual que se estabeleceu entre povos indígenas e comunidade envolvente. A segunda é, fundamentalmente, o caráter conflituoso dessas relações. 
Movimentos indígenas latino-americanos da segunda metade do século XX: reflexões comparativas sobre processos decoloniais no Brasil e na Colômbia

Tais características e os procedimentos que conformaram essas relações foram durante muito tempo, e ainda hoje o são, mascaradas por representações que sutilmente naturalizam a condição marginalizada na qual os índios se encontram na estrutura da sociedade contemporânea. É por conta disso que consideramos insuficiente qualquer representação que se proponha a justificar o lugar periférico dos povos indígenas na sociedade ou que intencione mascarar as injustiças cometidas contra esses povos. Pois, apesar da opressão, os grupos indígenas sempre resistiram e agiram diante das forças que Ihes impunham o apagamento e a descaracterização cultural. As emergências políticas e sociais de grupos indígenas latino-americanos a partir da segunda metade do século $X X$, informadas aqui entre um comparativo dos casos ocorridos no Brasil e na Colômbia, são demonstrações elucidativas do protagonismo dos povos indígenas na contemporaneidade.

\section{REFERÊNCIAS}

ANDRADE, Luis. 25 años de la ONIC, un legado vivo de la resistencia indígena en Colombia. Revista Observatorio Étnico Cecoin, Bogotá, n. 2, p. 15-36, jul./ago. 2007.

ARAÚJO, Ana Valéria et al. Povos indígenas e a Lei dos" Brancos": o direito à diferença. Ministério da Educação, 2006. Disponível em: http://www.portal.anchieta.br/anexos/ livro-col-14-vias-03.pdf; Acesso em: 21 ago. 2019.

ARCHILA, Mauricio; GONZÁLEZ PIÑEROS, Nidia Catherine. Movimiento indígena Caucano: historia y política. Tunja: Editorial Universidad Santo Tomas, 2010.

BALLESTRIN, Luciana. América Latina e o giro decolonial. Revista Brasileira de Ciência Política, Brasília, n. 11, p. 89-117, maio/ago. 2013. Disponível em: http://www.scielo.br/ scielo.php?script=sci_arttext\&pid=S0103-33522013000200004; Acesso em: 25 nov. 2017.

BELFORT, Lucia Fernanda Inácio. A proteção dos conhecimentos tradicionais dos povos indígenas, em face da convenção sobre diversidade biológica. Dissertação (Mestrado em Direito)- Universidade Federal de Brasília, Brasília-DF, 2006. Disponível em: http://www. dominiopublico.gov.br/download/teste/arqs/cp148895.pdf; Acesso em: 21 ago. 2019.

BECKER, Simone; SOUZA, Olivia Carla Neves de; OLIVEIRA, Jorge Eremites de. A prevalência da lógica integracionista: negações à perícia antropológica em processos criminais do Tribunal de Justiça do Mato Grosso do Sul. Etnográfica, v. 17, n. 1, p. 97-120, 2013. 
Disponível em: https://journals.openedition.org/etnografica/2580\#quotation. Acesso em: 5 set. 2018.

BENGOA, José. La emergencia indígena en América Latina. México: Fondo de Cultura Económica, 2000.

BICALHO, Poliene Soares dos Santos. Protagonismo indígena no Brasil: movimento, cidadania e direitos (1970-2009). 2010. Tese (Doutorado em História) - Universidade de Brasília, Brasília, 2010. Disponível em: http://repositorio.unb.br/bitstream/10482/6959/1/2010_ PolieneSoaresdosSantosBicalho.pdf. Acesso em: 5 dez. 2017.

BICALHO, Poliene Soares dos Santos. As assembleias indígenas - o advento do movimento indígena no Brasil. OPSIS, Catalão, GO, v. 10, n. 1, p. 91-114, jan./jun. 2010. Disponível em: https://revistas.ufg.br/Opsis/article/view/9553/8474\#.Wia28VWnFOw. Acesso em: 5 dez. 2017.

BRASIL. Decreto n. 26, de 4 de fevereiro de 1991. Dispõe sobre a Educação Indígena no Brasil. Disponível em: http://www.planalto.gov.br/ccivil_03/decreto/1990-1994/D0026. htm; Acesso em: 21 ago. 2019.

BRASIL. Constituição da República Federativa do Brasil, 1988. Disponível em: http:// www.planalto.gov.br/ccivil_03/constituicao/constituicao.htm; Acesso em: 21 ago. 2019.

BRASIL. Lei n. 6.001, de 19 de dezembro de 1973. Dispõe sobre o Estatuto do Índio. Disponível em: http://www.planalto.gov.br/ccivil_03/Leis/L6001.htm; Acesso em: 21 ago. 2019.

BRASIL. Decreto-Lei n. 5.540, de 2 de junho de 1943. Considera "Dia do Índio" a data de 19 de abril. Disponível em: http://www2.camara.leg.br/legin/fed/declei/1940-1949/decretolei-5540-2-junho-1943-415603-publicacaooriginal-1-pe.html. Acesso em: 18 nov. 2017.

CAVALCANTE, Thiago Leandro Vieira. Colonialismo, território e territorialidade: a luta pela terra dos Guarani e Kaiowa em Mato Grosso do Sul. 2013. Tese (Doutorado em História)Universidade Estadual Paulista, Assis, SP, 2013. Disponível em: https://repositorio.unesp. $\mathrm{br} /$ bitstream/handle/11449/106620/cavalcante_tlv_dr_assis.pdf?sequence=1. Acesso em: 4 set. 2018.

CAVIEDES, Mauricio. El surgimiento de la Organización Nacional Indígena de Colombia, ONIC en el período de gobierno de Julio César Turbay (1978-1982). Colombia Etnias y Política, Bogotá, v. 4 n. 1, p. 142-59, jun. /jul. 2007.

COLOMBIA, Constitución (1991). Constitución Política de Colombia. Gaceta Constitucional, n. 114, del jueves, 4 de julio de 1991. 
Movimentos indígenas latino-americanos da segunda metade do século XX: reflexões comparativas sobre processos decoloniais no Brasil e na Colômbia

COMISSÃO PRÓ-ÍNDIO. Encontro de Lideranças Indígenas e Entidades de Apoio - Índios, Direitos Históricos. De 26 a 29 de abril de 1981. Cadernos da Comissão Pró Índio/SP, São Paulo, n. III, 1982. Disponível em: http://cpisp.org.br/wp-content/uploads/2019/02/ Indios_Direitos_Historicos.pdf. Acesso em: 11 dez. 2017.

CRUZ, Edwin. Multiculturalismo e interculturalismo. Una lectura comparada. Cuadernos Interculturales, Bogotá, v. 11, n. 20, p. 45-76, jan/jun. 2013.

CRUZ, Edwin. Los movimientos indígenas y la cuestión nacional en Bolivia y Ecuador: una genealogía del estado plurinacional. Revista Análisis Político. Bogotá, v. 23, n. 70, p. 125-52, 2010.

CUNHA, Manuela Carneiro da. Definições de índios e comunidades indígenas nos textos legais. In: SANTOS, Silvio Coelho dos et al. (Org.). Sociedades Indígenas e o direito: uma questão de Direitos Humanos. Florianópolis: UFSC/CNPQ, 1985.

FERNANDES, Fernando Roque; COELHO, Mauro Cezar. "Ame-o ou emancipe-o": contradições da emancipação nos discursos, práticas e representações dos/sobre os povos indígenas no Brasil (1970/1980). In: COELHO, Wilma de Nazaré Baía; COELHO, Mauro Cezar (Org.). Debates interdisciplinares sobre diversidade e educação. São Paulo: Editora Livraria da Física, 2018. Coleção Formação de Professores e Relações Étnico-Raciais, p. 13-46.

FERNANDES, Fernando Roque. Cidadanização e etnogêneses no Brasil: apontamentos a uma reflexão sobre as emergências políticas e sociais dos povos indígenas na segunda metade do século XX. Revista Estudos Históricos, Rio de Janeiro, v. 31, n. 63, p. 71-88, jan./ abr. 2018. Disponível em: http://www.scielo.br/pdf/eh/v31n63/2178-1494-eh-31-63-71. pdf. Acesso em: 28 jun. 2018.

FERREIRA, Eva Maria Luiz; FALCÃO, Mariana Silva. Os Kaiowá e Guarani como mão de obra nos ervais da Companhia Matte Larangeira (1890-1960). Revista de História da UEG, Anápolis, GO, v. 2, n. 2, p. 94-110, jul./dez. 2013. Disponível em: https://www.revista.ueg. br/index.php/revistahistoria/article/view/2020. Acesso em: 4 set. 2018.

GALVÃO, Maria Eduarda Capanema Guerra. A Marcha para o Oeste na experiência da expedição Roncador-Xingú. In: SIMPÓSIO NACIONAL DE HISTÓRIA DA ANPUH, 26., São Paulo, 2011. Anais [...]. Disponível em: http://www.snh2011.anpuh.org/resources/ anais/14/1300890981_ARQUIVO_MarchaparaoOeste.pdf. Acesso em: 18 nov. 2017.

GARFIELD, Seth. As raízes de uma planta que hoje é o Brasil: os índios e o EstadoNação na era Vargas. Revista Brasileira de História, São Paulo, v. 20, n. 39, p. 13-36, 2000. Disponível em: http://www.scielo.br/scielo.php?script=sci_arttext\&pid=S0102$01882000000100002 \&$ lng=pt\&nrm=iso. Acesso em: 4 set. 2018. 
GRAHAM, Laura R. Citando Mario Juruna: imaginário linguístico e a transformação da voz indígena na imprensa brasileira. Mana, Rio de Janeiro, v. 17, n. 2, p. 271-312, ago. 2011. Disponível em: http://www.scielo.br/scielo.php?script=sci_arttext\&pid =S0104-93132011000200002. Acesso em: 11 dez. 2017.

HOUGHTON Juan Carlos. Desterritorialización y pueblos indígenas. In: HOUGHTON, Juan Carlos (Ed.). La tierra contra la muerte: conflictos territoriales de los pueblos indígenas en Colombia. Bogotá: CECOIN, 2008. p. 15-55. Disponível em: https://prensarural.org/spip/ IMG/pdf/10383_1_La_Tierra_contra_la_muerte.pdf\#page=15. Acesso em: 5 set. 2018.

LACERDA, Rosane Freire. "Volveré, y SeréMillones": contribuições descoloniais dos movimentos indígenas latino americanos para a superação do mito do Estado-Nação. 2014. Tese (Doutorado em Direito)- Universidade de Brasília (UnB), Brasília, DF, 2014. Disponível em: http://bdtd.ibict.br/vufind/Record/UNB_a115f51f61ea34b531b20a586bb43405. Acesso em: 5 dez. 2017.

LUCIANO BANIWA, Gersem José dos Santos. Movimentos e políticas indígenas no Brasil Contemporâneo. Tellus, Campo Grande, MS, ano 7, n. 12, p. 127-46, abr. 2007. Disponível em: http://tellus.ucdb.br/projetos/tellus/index.php/tellus/article/view/136/140. Acesso em: 15 jul. 2017.

LUCIANO BANIWA, Gersem José dos Santos. O índio brasileiro: o que você precisa saber sobre os povos indígenas no Brasil de hoje. Brasília: Ministério de Educação, SECAD, 2006. Disponível em: http://unesdoc.unesco.org/images/0015/001545/154565por.pdf. Acesso em: 5 set. 2018.

MALDONADO-TORRES, Nelson. Transdisciplinaridade e decolonialidade. Tradução de Joaze Bernandino-Costa. Sociedade e Estado, Brasília, v. 31, n. 1, p. 75-97, jan./abr. 2016. Disponível em: http://www.scielo.br/scielo.php?pid=S0102-69922016000100075\&script=sci_ arttext\&tlng=pt. Acesso em: 5 dez. 2017.

MUELAS HURTADO, Lorenzo. Os povos indígenas e a Constituição da Colômbia: primeira experiência de participação indígena nos processos constituintes da América Latina. In: RAMOS, Alcida Rita (Org.). Constituições nacionais e povos indígenas. Belo Horizonte: Ed. UFMG, 2012. p. 36-52.

MUNDURUKU, Daniel. O caráter educativo do movimento indígena brasileiro (1970-1990). São Paulo: Paulinas, 2012a.

MUNDURUKU, Daniel. "Posso ser quem você é sem deixar de ser o que sou": a gênese do movimento indígena brasileiro. In: LUCIANO, Gersem José dos Santos; HOFFMANN, 
Movimentos indígenas latino-americanos da segunda metade do século XX: reflexões comparativas sobre processos decoloniais no Brasil e na Colômbia

Maria Barroso; OLIVEIRA, Jô Cardoso de. Olhares indígenas contemporâneos II. Brasília: Centro Indígena de Estudos e Pesquisas-CINEP, 2012b. p. 104-19.

OLIVEIRA, João Pacheco de. Contexto e horizonte ideológico: reflexões sobre o Estatuto do Índio. In: SANTOS, Silvio Coelho dos et al. (Org.). Sociedades Indígenas e o direito: uma questão de Direitos Humanos. Florianópolis: UFSC/CNPQ, 1985. p. 17-30.

POUTIGNAT, Philippe; STREIFF-FENART, Jocelyne; BARTH, Fredrik. Teorias da etnicidade: seguido de grupos étnicos e suas fronteiras. São Paulo: Editora UNESP, 2011.

QUIJANO, Aníbal. Colonialidad del poder, globalización y democracia. Tendencias básicas de nuestra época: globalización y democracia, 2000. Disponível em: http://rrojasdatabank. info/pfpc/quijan02.pdf. Acesso em: 5 set. 2018.

QUIJANO, Aníbal. Colonialidad del poder, eurocentrismo y América Latina. In: LANDER, Edgardo (Comp.). La colonialidad del saber: eurocentrismo y ciencias sociales. Perspectivas latinoamericanas. Buenos Aires: CLACSO, 2000.

RESTREPO, Eduardo. Teorías contemporáneas de la etnicidad: Stuart Hall y Michel Foucault. Popayán, Colômbia: Universidad Del Cauca, 2004.

RIBEIRO, Darcy. Os índios e a civilização: a integração das populações indígenas no Brasil moderno. Petrópolis, RS: Vozes, 1982 [1970].

SILVA, Walter Guedes. A estratégia de integração do sul do estado de Mato Grosso ao território nacional durante o governo Vargas: uma análise a partir da criação da colônia agrícola nacional de Dourados em 1943. Revista do Departamento de Geografia, São Paulo, v. 31, p. 26-42, 2016. Disponível em: https://www.researchgate.net/ publication/305804846_A_ESTRATEGIA_DE_INTEGRACAO_DO_SUL_DO_ESTADO_DE_ MATO_GROSSO_AO_TERRITORIO_NACIONAL_DURANTE_O_GOVERNO_VARGASUMA_ ANALISE_A_PARTIR_DA_CRIACAO_DA_COLONIA_AGRICOLA_NACIONAL_DE_ DOURADOS_EM_1943. Acesso em: 4 set. 2018.

TERENA, Marcos. União das Nações Indígenas. In: ÍNDIOS: direitos históricos. Cadernos da Comissão Pró-Índio, n. 3. São Paulo, 1982. Disponível em: http://cpisp.org.br/wp-content/ uploads/2019/02/Indios_Direitos_Historicos.pdf. Acesso em: 12 dez. 2017.

VAZQUEZ CARRIZOSA, Alfredo. Historia critica del Frente Nacional. Bogotá: Ediciones Foro Nacional por Colombia, 1992. p. 63-111.

VIVEIROS DE CASTRO, Eduardo. "No Brasil, todo mundo é índio, exceto quem não é". Povos Indígenas no Brasil (2001/2005), p. 41-9, 2006. Disponível em: https://pib.socioambiental. 
org/files/file/PIB_institucional/No_Brasil_todo_mundo_\%C3\%A9_\%C3\%ADndio.pdf. Acesso em: 18 nov. 2017.

WALSH, Catherine. Interculturalidad y colonialidad del poder. In: CASTRO-GÓMEZ, Santiago; GROSFOGUEL, Ramón (Ed.). El giro decolonial. Reflexiones para una diversidad epistémica más allá del capitalismo global. Bogotá: Siglo del Hombre Editores; Universidad Central, Instituto de Estudios Sociales Contemporáneos y Pontificia Universidad Javeriana, Instituto Pensar, 2007. p. 47-62.

\section{Sobre os autores:}

Fernando Roque Fernandes - Doutorando em História Social da Amazônia pelo Programa de Pós-Graduação em História (PPHIST) da Universidade Federal do Pará (UFPA). Mestre em História Social pelo Programa de Pós-Graduação em História (PPGH) da Universidade Federal do Amazonas (UFAM). Professor de História Regional do Brasil pela Universidade Federal de Rondônia (UNIR). E-mail: fernando.fernandes@unir.br

Mauricio Alejandro Diaz Uribe - Doutorando no Programa de Pós-Graduação em História Social das Relações Políticas da Universidade Federal do Espírito Santo (UFES). Mestrado em Estudios Latinoamericanos pela Universidad Nacional de General San Martín. Graduação em Antropologia pela Universidad Nacional de Colombia - Bogotá. Tem experiência na área de Antropologia, com ênfase em políticas sociais. E-mail: madiazul@gmail.com

Recebido em 28 de junho de 2018

Aprovado para publicação em 01 de outubro de 2018 